\title{
Foreshock-mainshock-aftershock sequence analysis of the 14 January 2021 (Mw 6.2) Mamuju-Majene (West Sulawesi, Indonesia) earthquake
}

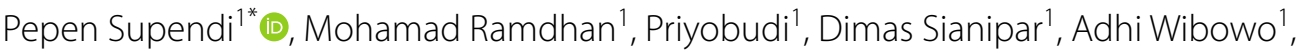 \\ Mohamad Taufik Gunawan', Supriyanto Rohadi', Nelly Florida Riama', Daryono', Bambang Setiyo Prayitno', \\ Jaya Murjaya ${ }^{1}$, Dwikorita Karnawati', Irwan Meilano², Nicholas Rawlinson ${ }^{3}$, Sri Widiyantoro ${ }^{4,5}$, \\ Andri Dian Nugraha ${ }^{4}$, Gayatri Indah Marliyani ${ }^{6}$, Kadek Hendrawan Palgunadi ${ }^{7}$ and Emelda Meva Elsera ${ }^{8}$
}

\begin{abstract}
We present here an analysis of the destructive Mw 6.2 earthquake sequence that took place on 14 January 2021 in Mamuju-Majene, West Sulawesi, Indonesia. Our relocated foreshocks, mainshock, and aftershocks and their focal mechanisms show that they occurred on two different fault planes, in which the foreshock perturbed the stress state of a nearby fault segment, causing the fault plane to subsequently rupture. The mainshock had relatively few aftershocks, an observation that is likely related to the kinematics of the fault rupture, which is relatively small in size and of short duration, thus indicating a high stress-drop earthquake rupture. The Coulomb stress change shows that areas to the northwest and southeast of the mainshock have increased stress, consistent with the observation that most aftershocks are in the northwest.
\end{abstract}

Keywords: Mamuju-Majene, Earthquake, Relocation, Rupture, Stress-change

\section{Introduction}

On January 14, 2021, a destructive earthquake (Mw 6.2) between Mamuju and Majene, West Sulawesi, Indonesia, occurred at 18:28 UTC (red star in Fig. 1). This event was preceded by a Mw 5.9 foreshock on the same day at 06:35 UTC (Fig. 2). Based on the shakemap from the Agency for Meteorology, Climatology, and Geophysics (BMKG), the earthquake produced strong ground motion with a V-VI MMI scale in West Sulawesi, caused severe damage to more than 279 houses and resulted in 84 fatalities (National Disaster Management Authority/NDMA). Peak Ground Acceleration (PGA) values of the Mw 6.2

\footnotetext{
*Correspondence: pepen_geophysics@yahoo.com

${ }^{1}$ Agency for Meteorology, Climatology, and Geophysics, Jakarta 10720, Indonesia

Full list of author information is available at the end of the article
}

mainshock from two of the nearest stations in Mamuju and Majene are 95.9 and 92.8 Gals, respectively, equivalent to VI on the MMI scale (Additional file 1: Figure S1). Over the past five decades, there have been two deadly earthquakes around Mamuju and Majene (see red stars in Fig. 1). The $M 7.0$ (23 February 1969) earthquake and tsunami resulted in 61 casualties (Prasetya et al. 2001), and the $M 7.0$ (8 January 1984) earthquake resulted in two casualties (Lander et al. 2003). The purpose of this study is to analyze the 2021 (Mw 6.2) Mamuju-Majene earthquake and its foreshocks and aftershocks through hypocenter relocation, focal mechanism solutions, and analysis of fault rupture process and stress changes.

The island of Sulawesi is located within a complex tectonic region at the confluence of the Eurasian, IndoAustralian and Philippine plates (Hall et al. 2011; Watkinson 2011). The geology of the area records the complex 


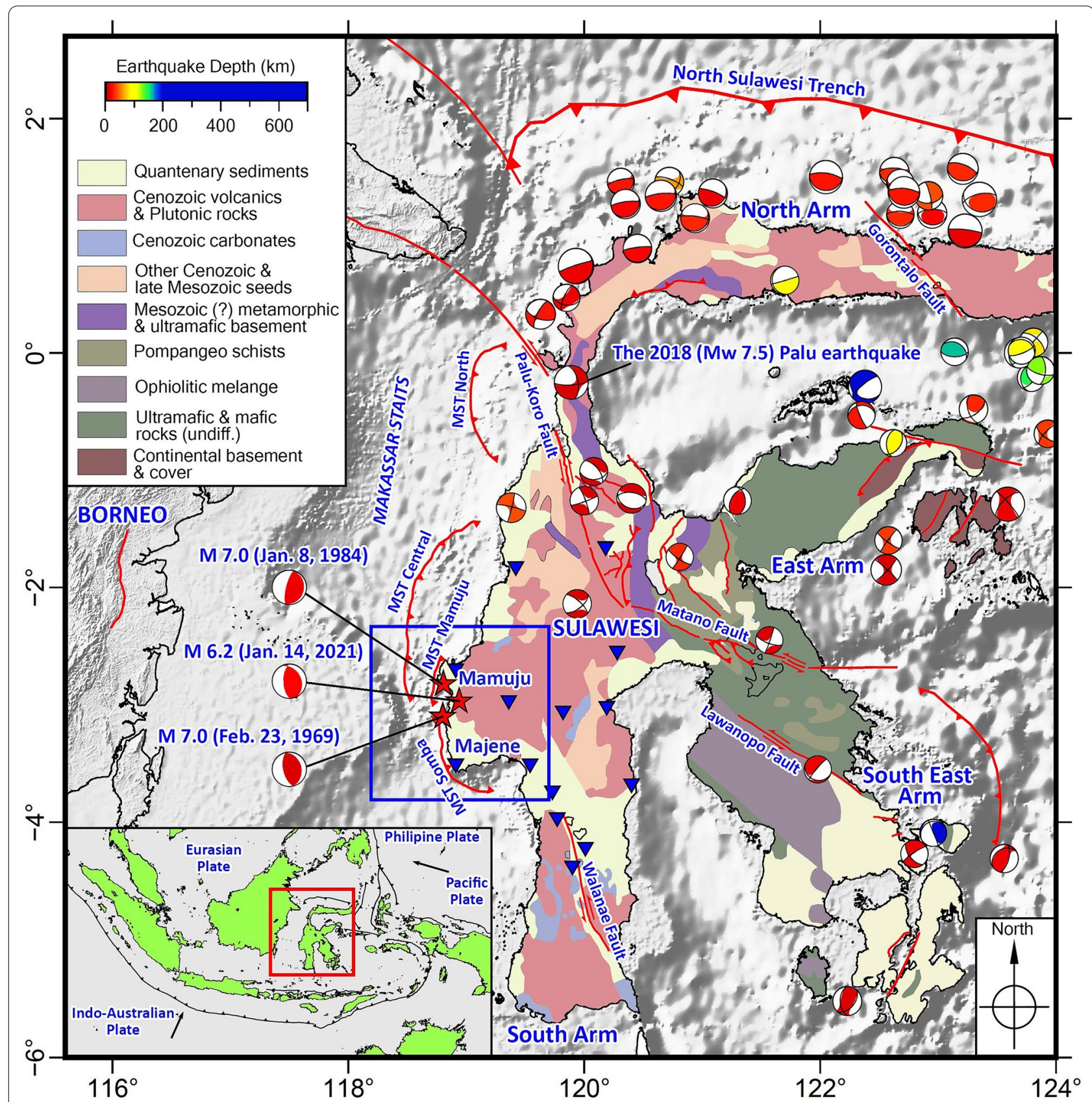

Fig. 1 Map of the Sulawesi region, with the study area denoted by a blue box. Geological features are taken from Watkinson (2011). The three red stars depict the 15 January 2021 (Mw 6.2) mainshock from BMKG and the historical destructive earthquakes around Mamuju are taken from the USGS earthquake catalog. The historical seismicity $(M \geq 6.0)$ and Centroid Moment Tensor (CMT) solutions for the entire Sulawesi region in the time period 1977 to 2020 are taken from the global CMT catalog, except for the 1969 (M 7.0) event taken from Fitch (1972) and the 2021 (M 6.2) event from the BMKG catalog. The blue inverted triangles are the BMKG seismic stations used in earthquake relocation process; red traces represent major crustal faults in the region extracted from Irsyam et al. (2017). The inset map shows the Indonesian region, together with Indo-Australian and Pacific plate motions relative to the Eurasian plate

history of subduction, extension, obduction, and collision of continental fragments during the Mesozoic-Cenozoic Era (e.g., Katili 1978; Hamilton 1979; Hall 2002). The island forms a unique " $k$ " shape with four elongated arms (known as the north, east, southeast, and south arms) consisting of distinct lithological assemblages (Fig. 1). The E-W oriented north arm consists of a Neogene island arc rock assemblage with a mix of oceanic 


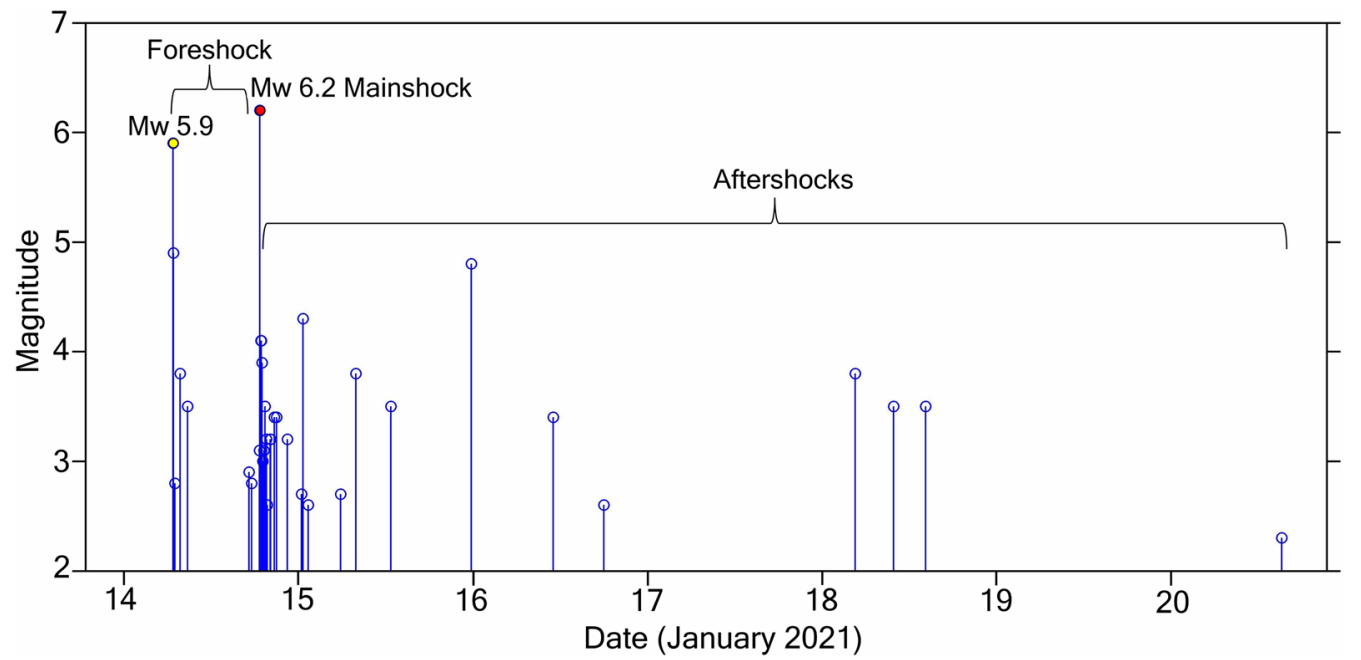

Fig. 2 Magnitude vs time for foreshocks, mainshock, and aftershocks of Mamuju-Majene earthquake. The detection threshold of our analysis is $M$ 2.3

continental crustal fragments (Elburg et al. 2002; Leeuwen et al. 2007). This arm connects to the main island by a narrow mountainous range composed of metamorphic and ultramafic basement (Sukamto 1973). The east and southeast arms are characterized by highly deformed ophiolite imbricated onto Mesozoic and Cenozoic sediment units (e.g., Hamilton 1979; Simandjuntak 1986; Parkinson 1991). Western Sulawesi is characterized by Miocene-Pliocene magmatic arc rocks, dominated by granitic intrusions through a basement of Cenozoic volcaniclastic and Mesozoic metamorphic rocks (Elburg et al. 2002; Hamilton 1979; Hall and Wilson 2000). All of these rock units have been accreted onto the southeastern margin of Sundaland, the continental core of southeast Asia, since the Middle Cretaceous (Hamilton 1979; Parkinson et al. 1998; Hall et al. 2009), with rapid uplift occurring during the Pliocene and continuing to present day (Bellier et al. 2006). All of these rock units are dissected by many deep-seated major fault systems, such as the Palu-Koro, Matano, Gorontalo, Lawanopo, and Walanea faults (Fig. 1).

In the north, the present day tectonic configuration is dominated by the North Sulawesi subduction zone with a convergence rate of $42-50 \mathrm{~mm} /$ year (Socquet et al. 2006). In the center, the structural configuration is mainly controlled by the Palu-Koro fault. This left-lateral strike-slip fault has a slip-rate of $42 \mathrm{~mm} /$ year (Socquet et al. 2006) and was the source of the 2018 ( Mw 7.5) destructive earthquake and tsunami (Gusman et al. 2019; Supendi et al. 2020). The western region of Sulawesi is characterized by the east-dipping Majene-Mamuju fold and thrust zone. The fold and thrust propagates to the west, where it is bounded by the Makassar Strait Thrust (MST) fault, which is composed of four segments (Irsyam et al. 2017). This fold and thrust zone accommodates most of the westerly accretion of Sulawesi towards the eastern limit of the Sundaland continent, and is the main source of seismicity in this region (Irsyam et al. 2017). Our study area is located in the vicinity of the Makassar Strait Thrust zone (Fig. 1).

\section{Data and method}

For this research, we use data from the BMKG earthquake catalog between 14 and 20 January 2021, which is based on recordings from BMKG permanent broadband stations (see the blue inverted triangles in Fig. 1). A total of 34 events of magnitude 2.3-6.2 were recorded by our stations during this period, including foreshocks, the mainshock, and aftershocks (Fig. 2) with 1316 and 187 identified $\mathrm{P}$ - and $\mathrm{S}$-wave arrival times, respectively. The initial hypocenters from the BMKG catalog were determined by using the linearized inversion scheme LocSAT (Bratt and Nagy 1991), which is part of the SeisComP3 program (Helmholtz-Centre Potsdam-GFZ German Research Centre For Geosciences and GEMPA GmbH 2008), in the presence of the IASP91 reference velocity model (Kennett and Engdahl 1991). For the relocation of foreshock, mainshock, and aftershock hypocenters, we use the HypoDD program (Waldhauser 2001) to perform the double-difference method (Waldhauser and Ellsworth 2000). HypoDD minimizes residuals between the observed and calculated travel-time differences via an iterative procedure, with the locations and partial derivatives updated after each iteration. We first applied 
a coupled velocity-hypocenter inversion using the program Velest (Kissling et al. 1994; Kissling 1995) to update a 1-D P-wave velocity model $\left(V_{\mathrm{p}}\right)$ derived from CRUST 1.0 (Laske et al. 2013) by exploiting data recorded by 14 of the BMKG seismic stations from 34 earthquakes. Due to the limited number of S-wave arrival times, we did not try and invert for a 1-D S-wave velocity model $\left(V_{\mathrm{s}}\right)$. Relative location uncertainties are estimated using a bootstrap method (Efron 1982; Billings 1994) for all relocated events. The synthetic data were calculated by adding Gaussian noise with a standard deviation of $0.1 \mathrm{~s}$ to all residuals. We relocated all events using the synthetic dataset and determined the perturbation from the original double-difference location. The process was repeated 1000 times, which allowed error ellipsoids at the 95\% confidence level to be estimated for each event. In order to further assess the influence of the dataset on the final event locations, we also randomly perturbed initial locations by adding Gaussian noise with a standard deviation of $10 \mathrm{~km}$ prior to relocation.

BMKG's focal mechanism solutions were determined by moment tensor inversion using the SCMTV program that is included in SeisComP3. This program applies the stable moment tensor inversion algorithm of Minson and Dreger (2008). The Green's functions were calculated using GEMINI (Friederich and Dalkolmo 1995) based on the IASP91 velocity model (Kennett and Engdahl 1991).

We obtain a rupture model of the mainshock by performing a finite fault inversion. The inversion is constrained by $\mathrm{P}$-wave teleseismic displacement data with good azimuthal coverage (Additional file 1: Figure S2a). The method is an inversion in the wavelet domain using a simulated annealing approach to search for the best estimates of the source model (Ji et al. 2002; Shao et al. 2011; Hao et al. 2013). The fault plane is constructed as a single rectangular east-dipping plane with a strike of $334^{\circ}$ and a dip of $32^{\circ}$, taken from BMKG's focal mechanism solution (Additional file 1: Figure S2b). We divided the fault plane into $772 \mathrm{~km} \times 2 \mathrm{~km}$ sub-faults. The size of this plane is first estimated by scaling according to Wells and Coppersmith (1994); however, we adjust the size of the plane during the inversion. In this model, the rupture was initiated from the relocated hypocenter (at a depth of $20 \mathrm{~km}$ ). Five unknowns are constrained for each sub-fault, i.e., the slip amplitude, rake angle, rupture initiation time, and two parameters describing the asymmetric source time function (Ji et al. 2003). A comparison between the observed and synthetic seismograms is available in Additional file 1: Figure S3. The finite fault inversion depends on many factors. Because we use only teleseismic displacement seismograms in this study (distance $30^{\circ}-90^{\circ}$ ), which have more reliable temporal resolution compared to of spatial and moment resolution, we can obtain the general picture of rupture propagation and a reliable slip amplitude. They can be represented by the source time functions we provide. Based on the finite fault model, we determined the Coulomb stress change of the co-seismic slip using Coulomb (Toda et al. 2011). We calculated stress changes for the optimal thrust fault (east-dipping plane with a strike of $334^{\circ}$ and a dip of $32^{\circ}$ ) at $\sim 20 \mathrm{~km}$ depth, assuming a friction coefficient of 0.4 and a Poisson ratio of 0.25 .

\section{Results and discussion}

We relocated seven foreshocks, a mainshock, and 24 aftershocks of the 2021 Mamuju-Majene earthquake from 14 to 20 January 2021 . We compared the relocated aftershocks with the initial locations (from the BMKG catalog) in map view and the vertical cross-section (Additional file 1: Figure S4). The events that had previously been held fixed at $10 \mathrm{~km}$ depth from the BMKG catalog have now been relocated using a double-difference method. Relative location errors are shown in Additional file 1: Figure S5. Based on the bootstrap analysis method described in "Data and method" section, average horizontal and vertical mislocations are generally less than $0.8 \mathrm{~km}$, and the corresponding maximum mislocations are less than $1.5 \mathrm{~km}$ (Additional file 1: Table S1, Figure S6). The test involving a random perturbation of the initial event locations prior to application of HypoDD reveals an average shift in relocation of $3.5 \mathrm{~km}$, which suggests that the data more strongly influences the final locations than the choice of initial locations. Additional file 1: Figure S7 illustrates the results from this test, which shows that the pattern of relocations is not significantly different.

The sequence associated with the Mw 6.2 MamujuMajene earthquake started with a foreshock of Mw 5.9 at 06:35 UTC; this was followed by six foreshocks with magnitudes less than $M 5.0$ in $12 \mathrm{~h}$ before the mainshock. Note that the detection threshold of the array is around $M 2.0$, so it is likely that there were many undetectable small foreshocks and aftershocks. Based on BMKG data analysis, both the Mw 5.9 foreshock and the Mw 6.2 mainshock occur on thrust faults (Fig. 3). We use the distribution of the relocated earthquakes and their focal mechanism solutions to assess candidates for the causative fault of this earthquake sequence (Fig. 3a). Figure 3b shows the profile of the fault rupture and our interpretation of the fault geometry based on the focal mechanism solution. The up-dip projection of the earthquake distribution in Fig. 3b suggests that the fault structure is located at MST Mamuju; the mainshock fault plane and aftershock hypocenter pattern appears to converge to MST Mamuju at the surface. The vertical cross-section shows most of the aftershocks are distributed across a 


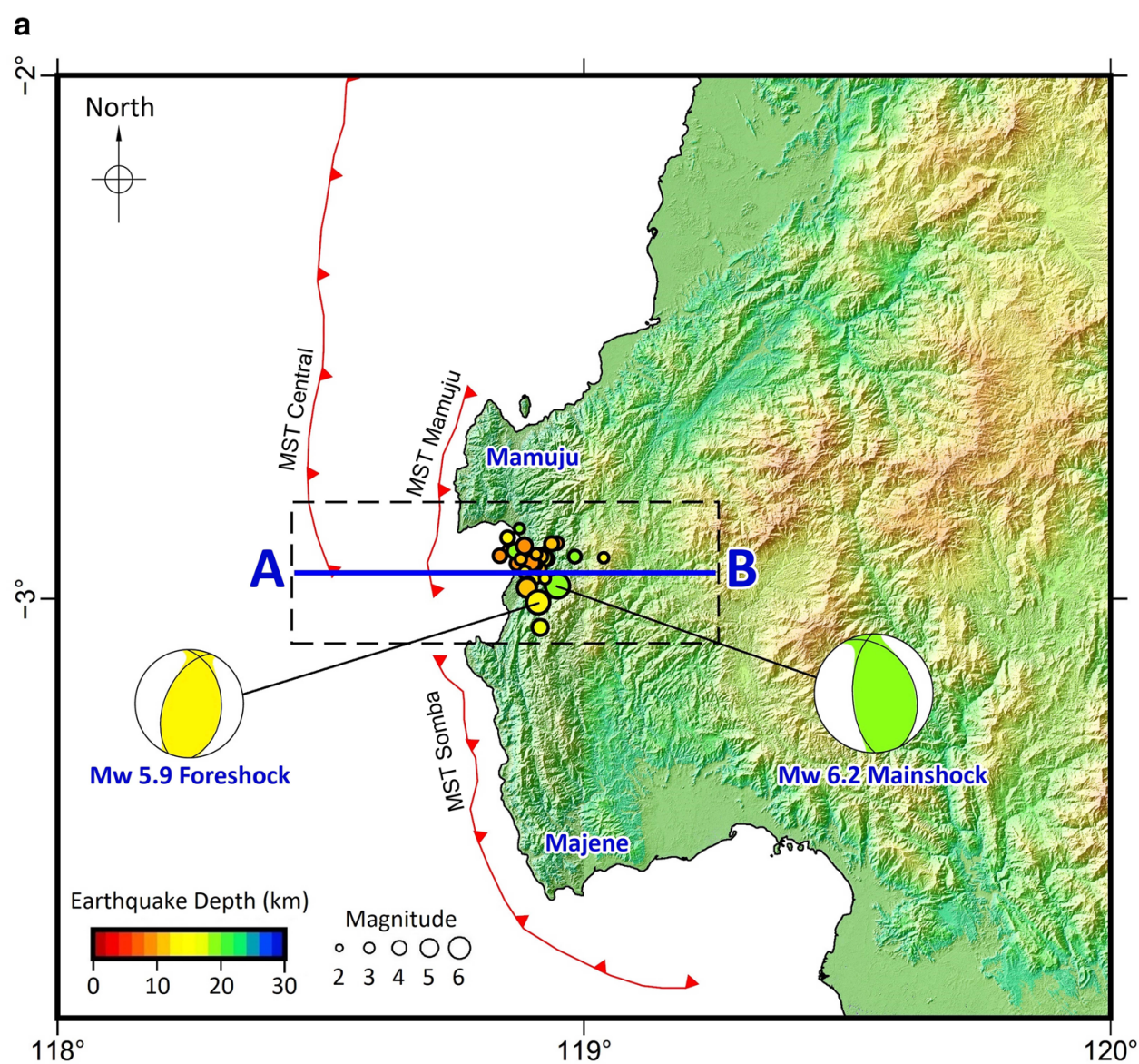

b

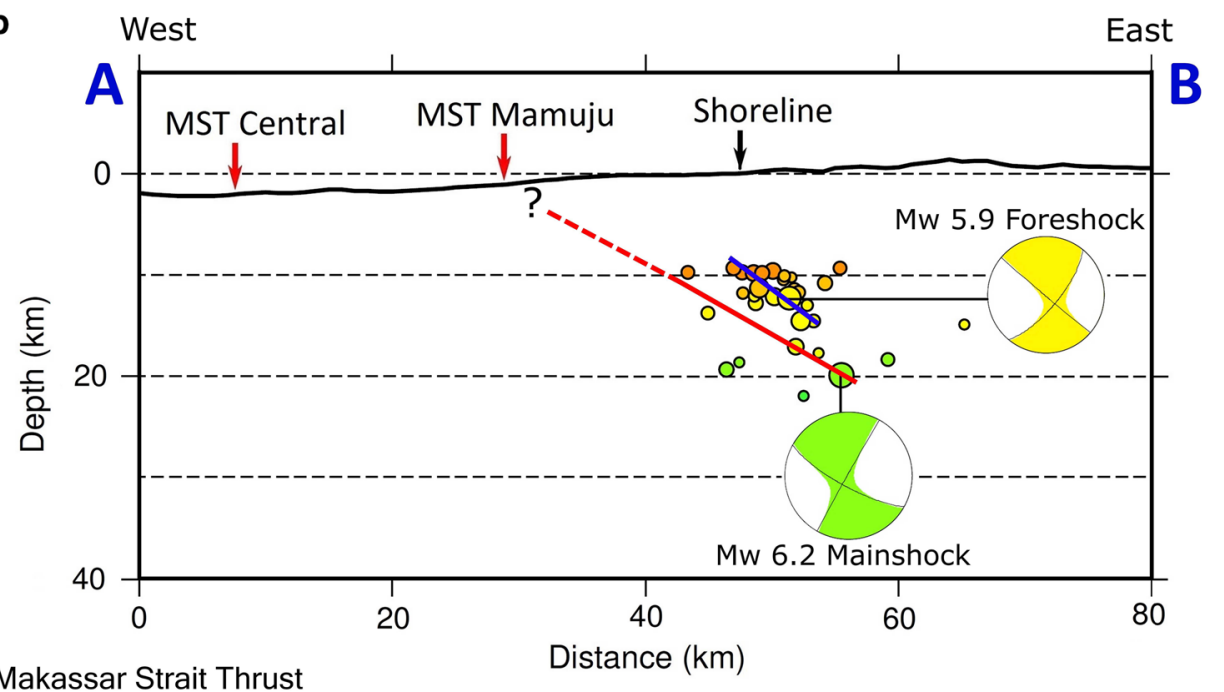

Fig. 3 a Map view of relocated events and focal mechanism solutions for a Mw 5.9 foreshock and the Mw 6.2 mainshock from the BMKG catalog; b cross-section A-B in West-East direction showing relocated events, focal mechanisms, and an interpretation of how multiple faults cause the earthquake sequence. The solid and dashed red lines suggest that the Mw 6.2 mainshock fault plane rupture is probably associated with MST Mamuju, while the solid blue line highlights the fault plane rupture based on the Mw 5.9 foreshock focal mechanism and aftershock hypocenter pattern 
depth range of 9-12 km, and within close proximity of the foreshock locations. There is only one aftershock recorded near the mainshock hypocenter. Based on the depth distribution of the foreshock and the mainshockaftershock sequence, we interpret that they occurred on two different fault planes. It is likely that the foreshock modified the stress state of a nearby fault segment, causing it to rupture. The relative locations and behavior of these two fault planes are depicted in Fig. 3b.

The development of fold and thrust belts in a highly compressive tectonic regime such as in Sulawesi is commonly known (Bergman et al. 1996; Puspita 2005; Morley et al. 2011; Wu et al. 2020). This fold and thrust belt may form a series of imbricated synthetic thrust faults (roof) seated on larger decollement thrust fault (floor thrust) (Yan et al. 2016). The 3D seismic images from Brackenridge et al. (2020) reveal the presence of a fold and thrust belt that cuts Pliocene-aged rock units off the west coast of Mamuju. This fold and thrust belt, is known as the Majene Fold and Thrust Belt. The Mw 5.9 foreshock and its associated foreshock events likely ruptured one of the roof thrusts. Meanwhile, the Mw 6.2 mainshock likely occurred on the floor thrust. The down-dip section of these two fault planes might be connected to one another via a decollement (hidden fault) of unknown depth.

Unlike other destructive crustal earthquakes of similar scale ( M6) in Indonesia, i.e., the 2006 (Mw 6.4) Yogyakarta earthquake (Walter et al. 2008; Budiman et al. 2019), the 2016 (Mw 6.6) Poso earthquake (Supendi et al. 2018; Wang et al. 2019), the 2016 (Mw 6.5) Pidie Jaya earthquake (Muzli et al. 2018), all of which had many aftershocks, the 2021 (Mw 6.2) Mamuju-Majene earthquake had fewer aftershocks.

The limited aftershocks caused by this earthquake are likely related to the kinematics of its source, which involves a relatively high moment release over a small source area and with a short duration (Fig. 4). We find that the primary moment release occurred within $4 \mathrm{~s}$ after the rupture initiated, with the peak slip of up to $180 \mathrm{~cm}$ at a depth of about $17-21 \mathrm{~km}$. The asperity (with slip $>50 \mathrm{~cm}$ ) has an average slip of about $106 \mathrm{~cm}$, across an effective length of only $\sim 8 \mathrm{~km}$. The rupture appears to have propagated monotonically updip. The static stress drop is estimated from the Kanamori and Anderson (1975) formula for circular rupture, by assuming a rigidity of $42.9 \mathrm{GPa}$ as derived from the CRUST 1.0 model (Laske et al. 2013), with an average slip of $106 \mathrm{~cm}$, and effective length of $8 \mathrm{~km}$, which produces a stress drop at the asperity of about 78 bars, much higher than the average stress drop of $\sim 40$ bars typically reported at active deformation zones (Ye et al. 2016). Based on source studies of aftershocks of the 2010 (Mw 8.8) Maule earthquake, Sen et al. (2015)

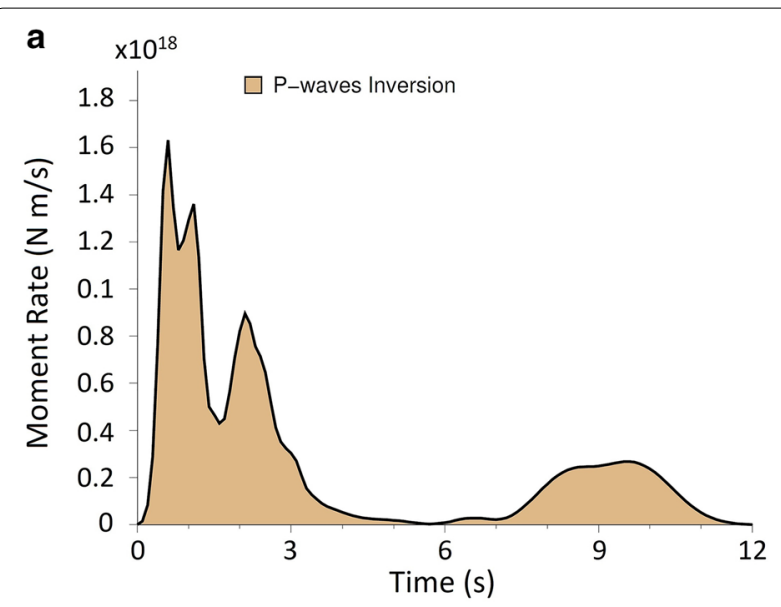

b

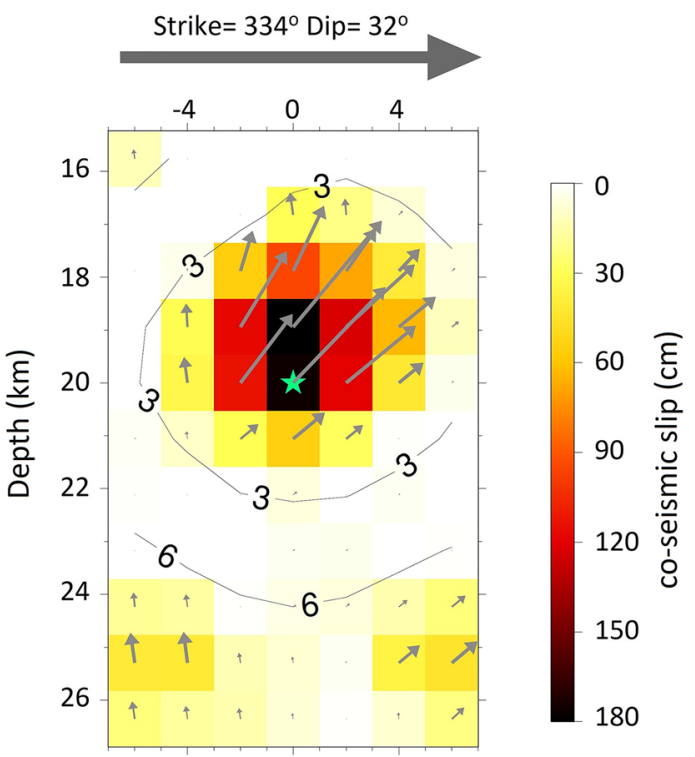

Fig. 4 a Moment rate function and $\mathbf{b}$ slip distribution, of the Mw 6.2 Mamuju-Majene mainshock. The gray arrows indicate the slip (rake) direction while the numbers (e.g., 3) indicate the rupture propagation time in seconds. The color represents the co-seismic slip in cm

suggested that depth-dependent variations in rigidity, rather than frictional conditional stability at the plate interface, is responsible for variations in source durations at subduction zones. This may also be the case in our study, even though it is not at a plate margin. Similarly, Sallarès and Ranero (2019) suggest that shallower events (usually near the trench) have a longer duration, with lower radiation frequencies. By contrast, deeper events like the 2021 Mamuju earthquake (depth $\sim 20 \mathrm{~km}$ ) tend to be of shorter duration and exhibit higher radiation frequencies.

Seismic stations near the earthquake epicenter recorded high-frequency ground motion (Additional file 1: Figure S8). The primary moment release duration 
of $4 \mathrm{~s}$ for the Majene earthquake is short and is certainly much faster than the $13 \mathrm{~s}$ of a typical rupture of a comparable magnitude 6.2 estimated from an empirical relationship (Ekström and Engdahl 1989). As observed in other studies, the production of aftershocks is largely controlled by the rupture's aspect ratio and stress drop, and to a lesser degree, by the down-dip width (DascherCousineau et al. 2020). A recent study from Miller
(2020) also shows that a lack of aftershocks can be due to the absence of high-pressure fluid sources at depth.

The Coulomb stress change relative to an $\mathrm{Mw} 6.2$ mainshock (Fig. 5) shows areas of increasing stress (depicted in red), towards the northwest of the mainshock, while the areas that have a stress drop (depicted in blue) are towards the southwest relative to the mainshock. The Coulomb stress change may explain the aftershock distributions and the approximate distribution of future

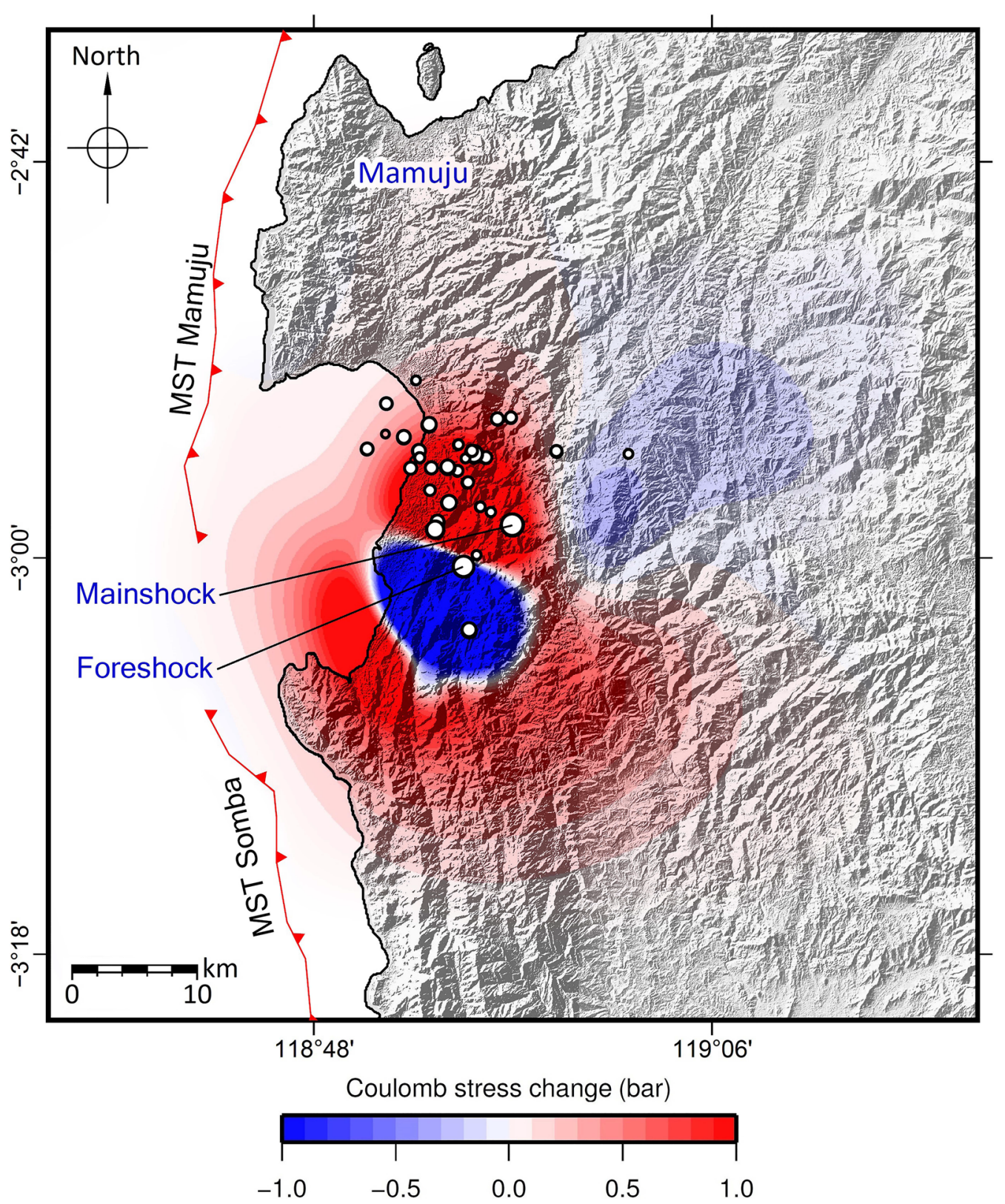

Fig. 5 Modeled Coulomb stress change caused by the Mw 6.2 mainshock of the Mamuju-Majene earthquake. We calculated stress changes for an optimal thrust fault at $\sim 20 \mathrm{~km}$ depth, with a coefficient of friction of 0.4 and Poisson's ratio of 0.25 . The blue and red colors depict negative and positive Coulomb stress changes, respectively. The white circles denote foreshocks, the mainshock, and aftershocks 
earthquakes (Stein and Lisowski 1983; King et al. 1994). It is likely that the mainshock energy release immediately reduced stress at the rupture location; this stress then transferred to the northwest and caused aftershocks, since this area exhibits a high Coulomb stress change (close to 1 Bar).

Based on the PGA map at bedrock (with $V_{\mathrm{s}}$ between 750 and $1500 \mathrm{~m} / \mathrm{s}$ ) for $2 \%$ probability of exceedance in 50 years (Irsyam et al. 2020), West Sulawesi has a modeled PGA value of less than $1 \mathrm{~g}$. However, many houses and buildings were severely damaged, and even some government buildings collapsed in Mamuju and Majene. The geological map from Hall and Wilson (2000) shows that the damaged areas are located in quaternary sediments, which likely explains the increased ground motion which peaks at around 96 Gal. Destructive earthquakes have struck in this area in the past (Fig. 1 and Additional file 1: Figure S9). Therefore, spatial and regional planning should use an updated earthquake hazard map that accounts for this earthquake sequence and the ground motion it produced.

\section{Concluding remarks}

The Mamuju-Majene earthquakes were likely caused by movement on faults within the Majene Fold and Thrust belt, in which the foreshock and mainshock occurred on two different fault planes. The unusually small number of aftershocks that occurred after this earthquake is likely related to the geometry of the fault rupture, and also to the short duration of the rupture. The mainshock increased stresses in the northwest area, as indicated by the high Coulomb stress change, which coincides with the distribution of aftershocks in this area.

\section{Supplementary Information}

The online version contains supplementary material available at https://doi. org/10.1186/s40623-021-01436-x.

Additional file 1: Figure S1. Three-component ground motion waveform of the Mw 6.2 mainshock from (a) Mamuju station, (b) Majene station. Mainshock epicenter distances to stations are $34.25 \mathrm{~km}$ and 63.17 km, respectively. Note that $1 \mathrm{~g}=980 \mathrm{Gals}$. Figure S2. (a) Teleseismic stations used to constrain source rupture model; (b) location of the mainshock and focal mechanism solution from BMKG. Figure S3. Comparison of the P-wave (vertical component) observed (black line) and synthetic (red line) waveforms for source rupture model. Figure S4. Map view and vertical cross sections showing the foreshock, mainshock, and aftershocks. (a) Initial location from the BMKG catalog, (b) after relocation from the hypoDD relative relocation routine (a total of 32 events). Figure S5. (a) Map view of relative location errors for the foreshocks, mainshock, and aftershocks of the Mamuju-Majene earthquake; (b) longitude slice; and (c) latitude slice. Figure $\mathbf{S} 6$. Histograms of lateral and vertical relative location errors of double-difference solutions for the Mamuju-Majene earthquakes. Errors are computed from the major axes of the horizontal and vertical projection of the $95 \%$ confidence ellipsoids obtained from a bootstrap analysis of the final double-difference vector based on 1000 samples with replacement. Table S1. Horizontal (DX, DY) and vertical (DZ) location errors computed from the Bootstrap approach with Gaussian noise $(0.1 \mathrm{~s})$ added to the forehocks, mainshock, and aftershocks of the Mamuju-Majene earthquake. Figure S7. Results from undertaking a test in which the relocation is carried out using starting locations that have been randomly perturbed from their original value by adding noise with a standard deviation of $10 \mathrm{~km}$. (a) Map view; (b) E-W slice; (c) N-S slice showing the original relocations as red dots and the new relocations as blue dots; (d) frequency histogram showing the distribution of the differences between new and original relocations. Figure S8. Recorded ground motion and its power spectra from (a) Mamuju station; (b) Majene station. Figure S9. The 2021 Mamuju-Majene earthquake (red dots) overlaid on the 1969 events (blue dots), and the 1984 events (green dots) and associated aftershocks. The focal mechanism solution is taken from Fitch (1972) for the 1969 event, the Global CMT catalog for the 1984 event, and the BMKG catalog for the 2021 event.

\section{Acknowledgements}

We thank the Agency for Meteorology, Climatology, and Geophysics (BMKG) of Indonesia for granting access to the earthquake data catalog used in this study.

\section{Authors' contributions}

PS performed the hypocenter relocation and analysis, MR performed velocity model update, DS performed the source model and stress change and analysis, KHP performed the Bootstrap analysis. All authors have reviewed and contributed to the preparation of the manuscript. All authors read and approved the final manuscript.

\section{Funding}

This research was supported and funded by Komite Kajian Gempabumi dan Tsunami BMKG 2021.

\section{Availability of data and materials}

The earthquake catalog and focal mechanism used in this study was extracted from BMKG. The fault data are taken from Irsyam et al. (2017). Topography and bathymetry data were taken from Digital Elevation Model Nasional (http:// tides.big.go.id/DEMNAS/). All figures were made using The Generic Mapping Tools (Wessel and Smith 1998). The earthquake relocation catalog is available at https://doi.org/10.5281/zenodo.4643059

\section{Declarations}

\section{Competing interests}

We declare that we have no significant competing financial, professional or personal interests that might have influenced the performance or presentation of the work described in this manuscript.

\section{Author details}

${ }^{1}$ Agency for Meteorology, Climatology, and Geophysics, Jakarta 10720, Indonesia. ${ }^{2}$ Faculty of Earth Science and Technology, Institute of Technology Bandung (ITB), Bandung, Indonesia. ${ }^{3}$ Department of Earth Sciences-Bullard Labs, University of Cambridge, Cambridge CB30EZ, UK. ${ }^{4}$ Global Geophysics Research Group, Faculty of Mining and Petroleum Engineering, Institut Teknologi Bandung, Bandung 40132, Indonesia. ${ }^{5}$ Faculty of Engineering, Maranatha Christian University, Bandung 40164, Indonesia. ${ }^{6}$ Geological Engineering Department, Gadjah Mada University, Yogyakarta 55281, Indonesia. ${ }^{7}$ Physical Science and Engineering, King Abdullah University of Science and Technology, Thuwal, Saudi Arabia. ${ }^{8}$ Agency for Meteorology, Climatology, and Geophysics, Makasar 90231, Indonesia.

Received: 5 February 2021 Accepted: 7 May 2021

Published online: 17 May 2021 


\section{References}

Bellier O, Sébrier M, Seward D, Beaudouin T, Villeneuve M, Putranto E (2006) Fission track and fault kinematics analyses for new insight into the Late Cenozoic tectonic regime changes in West-Central Sulawesi (Indonesia) Tectonophysics 413:201-220. https://doi.org/10.1016/j.tecto.2005.10.036

Bergman SC, Coffield DQ, Talbot JP, Garrard RA (1996) Tertiary Tectonic and magmatic evolution of western Sulawesi and the Makassar Strait, Indonesia: evidence for a Miocene continent-continent collision. Geol Soc Lond Spec Publ 106:391-429. https://doi.org/10.1144/GSL.SP.1996.106.01.25

Billings SD (1994) Simulated annealing for earthquake location. Geophys J Int 118:680-692. https://doi.org/10.1111/j.1365-246X.1994.tb03993.x

Brackenridge RE, Nicholson U, Sapiie B, Stow D, Tappin DR (2020) Indonesian Throughflow as a preconditioning mechanism for submarine landslides in the Makassar Strait. Geol Soc Lond Spec Publ 500:195-217. https://doi. org/10.1144/SP500-2019-171

Bratt SR, Nagy W (1991) The LocSAT program. Science Applications International Corporation (SAIC), San Diego

Budiman R, Sahara DP, Nugraha AD (2019) Determining Source model and aftershocks of 2006 Yogyakarta Earthquake, Indonesia using Coulomb stress change. IOP Conf Ser Earth Environ Sci 318:012026. https://doi.org/ 10.1088/1755-1315/318/1/012026

Dascher-Cousineau K, Brodsky EE, Lay T, Goebel THW (2020) What controls variations in aftershock productivity? J Geophys Res Solid Earth. https:// doi.org/10.1029/2019JB018111

Efron B (1982) The Jackknife, the bootstrap and other resampling plans. Society for Industrial and Applied Mathematics, Philadelphia. https://doi.org/ 10.1137/1.9781611970319

Ekström G, Engdahl ER (1989) Earthquake source parameters and stress distribution in the Adak Island region of the central Aleutian Islands, Alaska. J Geophys Res Solid Earth 94:15499-15519. https://doi.org/10.1029/JB094 iB11p15499

Elburg MA, Leeuwen TV, FodenMuhardjo J (2002) Origin of geochemical variability by Arc-Continent Collision in the Biru Area, Southern Sulawesi (Indonesia). J Petrol 43:581-606. https://doi.org/10.1093/petrology/43.4 581

Fitch TJ (1972) Plate convergence, transcurrent faults, and internal deformation adjacent to Southeast Asia and the western Pacific. J Geophys Res 77:4432-4460. https://doi.org/10.1029/JB077i023p04432

Friederich W, Dalkolmo J (1995) Complete synthetic seismograms for a spherically symmetric earth by a numerical computation of the Green's function in the frequency domain. Geophys J Int 122:537-550. https:// doi.org/10.1111/j.1365-246X.1995.tb07012.x

Gusman AR, Supendi P, Nugraha AD, Power W, Latief H, Sunendar H, Widiyantoro S, Daryono WSH, Hakim A, Muhari A, Wang X, Burbidge D, Palgunadi K, Hamling I, Daryono MD (2019) Source model for the Tsunami inside Palu Bay following the 2018 Palu Earthquake, Indonesia. Geophys Res Lett 46:8721-8730. https://doi.org/10.1029/2019GL082717

Hall R (2002) Cenozoic geological and plate tectonic evolution of SE Asia and the SW Pacific: computer-based reconstructions, model and animations. J Asian Earth Sci 20:353-431. https://doi.org/10.1016/S1367-9120(01) 00069-4

Hall R, Wilson MEJ (2000) Neogene sutures in eastern Indonesia. J Asian Earth Sci 18:781-808. https://doi.org/10.1016/S1367-9120(00)00040-7

Hall R, Clements B, Smyth HR (2009) Sundaland: basement character, structure and plate tectonic development. In: Proc Indon Petrol Assoc, 33rd annual convention

Hall R, Cottam MA, Wilson MEJ (2011) The SE Asian gateway: history and tectonics of Australia-Asia collision. Geol Soc Lond Spec Publ 355:1-6. https://doi.org/10.1144/SP355.1

Hamilton WB (1979) Tectonics of the Indonesian region. Tectonic of the Indonesian Region. US Geol Surv Prof Pap 1078, 345 pp

Hao J, Ji C, Wang W, Yao Z (2013) Rupture history of the $2013 M_{w} 6.6$ Lushan earthquake constrained with local strong motion and teleseismic body and surface waves: slip model of the 2013 Lushan earthquake. Geophys Res Lett 40:5371-5376. https://doi.org/10.1002/2013GL056876

Helmholtz-Centre Potsdam-GFZ German Research Centre for Geosciences, GEMPA GmbH (2008) The SeisComP seismological software package. GFZ Data Services

Irsyam M, Widiyantoro S, Natawidjaja DH, Meilano I, Rudyanto A, Hidayati S, Triyoso W, Hanifa NR, Djarwadi D, Faizal L, Sunarjito (eds) (2017) Peta sumber dan bahaya gempa Indonesia tahun 2017, Cetakan pertama. Pusat
Penelitian dan Pengembangan Perumahan dan Permukiman, Badan Penelitian dan Pengembangan, Kementerian Pekerjaan Umum, Bandung (in Indonesian)

Irsyam M, Cummins PR, Asrurifak M, Faizal L, Natawidjaja DH, Widiyantoro S, Meilano I, Triyoso W, Rudiyanto A, Hidayati S, Ridwan M, Hanifa NR, Syahbana AJ (2020) Development of the 2017 national seismic hazard maps of Indonesia. Earthq Spectra. https://doi.org/10.1177/8755293020951206

Ji C, Wald DJ, Helmberger DV (2002) Source description of the 1999 Hector Mine, California, earthquake, part I: wavelet domain inversion theory and resolution analysis. Bull Seismol Soc Am 92:1192-1207. https://doi.org/10. 1785/0120000916

Ji C, Helmberger DV, Wald DJ, Ma K-F (2003) Slip history and dynamic implications of the 1999 Chi-Chi, Taiwan, earthquake: slip history of the 1999 Chi-Chi Earthquake. J Geophys Res Solid Earth 108:2412. https://doi.org/ 10.1029/2002JB001764

Kanamori H, Anderson DL (1975) Theoretical basis of some empirical relations in seismology. Bull Seismol Soc Am 65:1073-1095

Katili JA (1978) Past and present geotectonic position of Sulawesi, Indonesia. Tectonophysics 45:289-322. https://doi.org/10.1016/0040-1951(78) 90166-X

Kennett BLN, Engdahl ER (1991) Traveltimes for global earthquake location and phase identification. Geophys J Int 105:429-465. https://doi.org/10. 1111/j.1365-246X.1991.tb06724.x

King GCP, Stein RS, Lin J (1994) Static stress changes and the triggering of earthquakes. Bull Seismol Soc Am 84:935-953

Kissling E (1995) Program VELEST user's guide-short introduction (second draft version). Institute of Geophysics, ETH Zurich, Zurich, p 26

Kissling E, Ellsworth WL, Eberhart-Phillips D, Kradolfer U (1994) Initial reference models in local earthquake tomography. J Geophys Res 99:19635-19646. https://doi.org/10.1029/93JB03138

Lander F, Whiteside LS, Lockridge PA (2003) Two decades of global tsunamis (1982-2002). Sci Tsunami Hazards 21(1):3-88

Laske G, Masters G, Ma Z, Pasyanos M (2013) Update on CRUST1.0_A 1-degree global model of earth's crust. Geophys Res 15, Abstract EGU2013-2658

Miller SA (2020) Aftershocks are fluid-driven and decay rates controlled by permeability dynamics. Nat Commun 11:5787. https://doi.org/10.1038/ s41467-020-19590-3

Minson SE, Dreger DS (2008) Stable inversion for the complete moment tenso algorithm. Geophys J Int 174:585-592. https://doi.org/10.1111/j.1365246X.2008.03797.X

Morley CK, King R, Hillis R, Tingay M, Backe G (2011) Deepwater fold and thrust belt classification, tectonics, structure and hydrocarbon prospectivity: a review. Earth-Sci Rev 104:41-91. https://doi.org/10.1016/j.earscirev.2010. 09.010

Muzli M, Umar M, Nugraha AD, Bradley KE, Widiyantoro S, Erbas K, Jousset P, Rohadi S, Nurdin I, Wei S (2018) The 2016 Mw 6.5 Pidie Jaya, Aceh, North Sumatra, earthquake: reactivation of an unidentified sinistral fault in a region of distributed deformation. Seismol Res Lett 89:1761-1772. https://doi.org/10.1785/0220180068

Parkinson CD (1991) The petrology, structure and geologic history of the metamorphic rocks of Central Sulawesi, Indonesia. PhD thesis (University of London)

Parkinson CD, Miyazaki K, Wakita K, Barber AJ, Carswell DA (1998) An overview and tectonic synthesis of the pre-Tertiary very-high-pressure metamorphic and associated rocks of Java, Sulawesi and Kalimantan, Indonesia. Is I Arc 7:184-200. https://doi.org/10.1046/j.1440-1738.1998.00184.x

Prasetya GS, De Lange WP, Healy TR (2001) The makassar strait Tsunamigenic Region, Indonesia. Nat Hazards 24:295-307. https://doi.org/10.1023/A: 1012297413280

Puspita SD (2005) Structural styles of the offshore West Sulawesi fold belt, North Makassar straits, Indonesia. In: Proc Indon Petrol Assoc 30th Ann Conv Indonesian Petroleum Association (IPA)

Sallarès V, Ranero CR (2019) Upper-plate rigidity determines depth-varying rupture behaviour of megathrust earthquakes. Nature 576:96-101. https://doi.org/10.1038/s41586-019-1784-0

Sen AT, Cesca S, Lange D, Dahm T, Tilmann F, Heimann S (2015) Systematic changes of earthquake rupture with depth: a case study from the 2010 $M_{\mathrm{w}} 8.8$ Maule, Chile, earthquake aftershock sequence. Bull Seismol Soc Am 105:2468-2479. https://doi.org/10.1785/0120140123 
Shao G, Li X, Ji C, Maeda T (2011) Focal mechanism and slip history of the 2011 M w 9.1 off the Pacific coast of Tohoku Earthquake, constrained with tele seismic body and surface waves. Earth Planet Space 63:559-564. https:// doi.org/10.5047/eps.2011.06.028

Simandjuntak TO (1986) sedimentology and tectonics of the collision complex in the east arm of Sulawesi, Indonesia. PhD Thesis, RHBNC University of London, UK

Socquet A, Simons W, Vigny C, McCaffrey R, Subarya C, Sarsito D, Ambrosius B, Spakman W (2006) Microblock rotations and fault coupling in SE Asia triple junction (Sulawesi, Indonesia) from GPS and earthquake slip vector data. J Geophys Res. https://doi.org/10.1029/2005JB003963

Stein RS, Lisowski M (1983) The 1979 Homestead Valley earthquake sequence, California: control of aftershocks and postseismic deformation. J Geophys Res 88:6477. https://doi.org/10.1029/JB088iB08p06477

Sukamto R (1973) Reconnaissance geological map of Palu area, Central Sulawesi. Scale 1:250.000, Geological survey of Indonesia

Supendi P, Nugraha AD, Widiyantoro S (2018) Hypocenter relocation of the aftershocks of the Poso, Sulawesi (Mw 6.6, May 29, 2017) event using the BMKG network data. In: AIP Conf Proc, pp 020076

Supendi P, Nugraha AD, Widiyantoro S, Pesicek JD, Thurber $\mathrm{CH}, \mathrm{Abdullah} \mathrm{Cl}$ Daryono D, Wiyono SH, Shiddiqi HA, Rosalia S (2020) Relocated aftershocks and background seismicity in eastern Indonesia shed light on the 2018 Lombok and Palu earthquake sequences. Geophys J Int 221:18451855. https://doi.org/10.1093/gji/ggaa118

Toda S, Stein RS, Sevilgen V, Lin J (2011) Coulomb 3.3 Graphic-rich deformation and stress-change software for earthquake, tectonic, and volcano research and teaching-user guide. USGS open file report 2011-1060, 63 p

van Leeuwen T, Allen CM, Kadarusman A, Elburg M, Palin JM, Muhardjo S (2007) Petrologic, isotopic, and radiometric age constraints on the origin and tectonic history of the Malino Metamorphic Complex, NW Sulawesi, Indonesia. J Asian Earth Sci 29:751-777. https://doi.org/10.1016/j.jseaes. 2006.05.002

Waldhauser F (2001) hypoDD-a program to compute double-difference hypocenter locations. USGS open file report 2001-113. https://doi.org/10. 3133/ofr01113

Waldhauser F, Ellsworth WL (2000) A double-difference earthquake location algorithm: method and application to the Northern Hayward Fault,
California. Bull Seismol Soc Am 90:1353-1368. https://doi.org/10.1785/ 0120000006

Walter TR, Wang R, Luehr B-G, Wassermann J, Behr Y, Parolai S, Anggraini A, Günther E, Sobiesiak M, Grosser H, Wetzel H-U, Milkereit C, Brotopuspito PJKS, Harjadi P, Zschau J (2008) The 26 May 2006 magnitude 6.4 Yogyakarta earthquake south of Mt. Merapi volcano: did lahar deposits amplify ground shaking and thus lead to the disaster? Geochem Geophys. https://doi.org/10.1029/2007GC001810

Wang S, Xu C, Xu W, Yin Z, Wen Y, Jiang G (2019) The 2017 Mw 6.6 poso earthquake: implications for extrusion tectonics in Central Sulawesi. Seismol Res Lett 90:649-658. https://doi.org/10.1785/0220180211

Watkinson IM (2011) Ductile flow in the metamorphic rocks of central Sulawesi. Geol Soc Lond Spec Publ 355:157-176. https://doi.org/10.1144/ SP355.8

Wells DL, Coppersmith KJ (1994) New empirical relationships among magnitude, rupture length, rupture width, rupture area, and surface displacement. Bull Seismol Soc Am 84:974-1002

Wessel P, Smith WHF (1998) New improved version of Generic Mapping Tools released. EOS Trans Am Geophys Union 79:579-579. https://doi.org/10. 1029/98EO00426

Wu J, McClay K, de Vera J (2020) Growth of triangle zone fold-thrusts within the NW Borneo deep-water fold belt, offshore Sabah, southern South China Sea. Geosphere 16:329-356. https://doi.org/10.1130/GES02106.1

Yan D-P, Xu Y-B, Dong Z-B, Qiu L, Zhang S, Wells M (2016) Fault-related fold styles and progressions in fold-thrust belts: insights from sandbox modeling: sandbox modeling the fold-thrust belts. J Geophys Res Solid Earth 121:2087-2111. https://doi.org/10.1002/2015JB012397

Ye L, Lay T, Kanamori H, Rivera L (2016) Rupture characteristics of major and great $\left(M_{w} \geq 7.0\right)$ megathrust earthquakes from 1990 to 2015: 1. Source parameter scaling relationships. J Geophys Res Solid Earth 121:826-844. https://doi.org/10.1002/2015JB012426

\section{Publisher's Note}

Springer Nature remains neutral with regard to jurisdictional claims in published maps and institutional affiliations.

\section{Submit your manuscript to a SpringerOpen ${ }^{\circ}$ journal and benefit from:}

- Convenient online submission

- Rigorous peer review

- Open access: articles freely available online

- High visibility within the field

- Retaining the copyright to your article

Submit your next manuscript at springeropen.com 